\title{
The Cultural Implications and Differences of Animal Vocabulary in English and Chinese
}

\author{
Siming Li \\ Yantai Nanshan Universuty \\ Yantai, Shandong, China 265700
}

\begin{abstract}
In the long civilization of human history, animals are closely connected with human beings and have profound effect on survival and development of human beings. The intimate relationship makes people form complex attitudes towards different animals, such as love, sympathy, disgust and fear, etc. People also use animals to convey and express human feelings, therefore there are many animal vocabularies in both English and Chinese cultures. Vocabularies reflect cultural difference. In English and Chinese, animal vocabularies are entitled specific cultural implications due to influences of history, customs, values and religious believes, etc.
\end{abstract}

Keywords-animal; culture; implications; differences

\section{INTRODUCTION}

As is known, under different languages and cultural backgrounds, each word not only has its denotation, but also profound cultural connotation, namely, its implied relevant meaning, metaphorical meaning, symbolic meaning as well as commendatory sense and derogatory sense. Many words about animals have different cultural implications in different languages. For example, "goat" brand clock made in China enjoys good reputation in the international market because of its high quality. But Englishmen totally ignore it because of its brand. In China, goat refers to a knowledgeable person, even kids in kindergarten know that elderly goat grandpa has lots of knowledge; whereas goat refers to randy frivolous man in English. Thereby, the same animal has different implications in different cultures. To analyze and compare the cultural implications and differences of animal vocabularies in Chinese and English from the point of cultural linguistics and comparative linguistics will benefit language study. Through the comparative study of the same, different or no implications of the same animal and the similar references of different animals in English and Chinese, we can see the cultural impact on vocabulary and it also vividly reveals the cultural differences in English and Chinese.

\section{The SAME CUltural IMPlicAtion OF THE SAME ANIMAL WORD IN ENGLISH AND CHINESE}

Because the ecological environment of human life is quite similar, English and Chinese people began to know animals from the point of basic property, naturally, they form the same or similar connection and grant the animal same cultural implication. For example: the English say: He is a fox. The Chinese understand it perfectly. We can see that fox is also used to mean a cunning person in English. Here is another phrase, as cunning as a fox. We can come to the conclusion that fox is granted the same cultural implication in different languages. There are many more such kind of animal vocabularies. Sheep is viewed as tame and meek animal in both Chinese and Western cultures and the word is used to mean meek and obedient.

Parrot is a kind of bird that can imitate human voice, and it is used to refer to a person who repeats somebody else's words or imitates his actions without thinking in both English and Chinese cultures. Wolf has greedy and cruel nature, so there is similar expression "as cruel as a wolf" in both Chinese and English. Pig has the implications of laziness, clumsiness and ugliness in addition to dirtiness and greediness, such as: eat like a pig; make a pig of oneself. Bee is the symbol of business and diligence in both languages, here is the phrase "as busy as a bee". Pigeon is the symbol of peace and is called "peace pigeon" by the Chinese. Ass refers to stupid idiot in both English and Chinese, here is the phrase "make an ass of oneself'.

\section{THE DifFERENT CULTURAL IMPLICATION OF THE SAME ANIMAL WORD IN ENGLISH AND CHINESE}

Because the English and Chinese people have lived in different cultural backgrounds for a long time, they naturally grant the same animal word different connections and richer cultural implications. The following is the analysis of differences in cultural implications of the same animal word in terms of traditional cultural difference and aesthetic value orientation.

\section{A. The Distinctive National Cultural Features of Some Animals Caused by Traditional Cultural Difference}

Dragon appears in Western and Oriental myths. But there are great differences for dragon in Chinese and English. In Chinese, dragon implies good luck and nobility whereas in English dragon implies evilness and cruelty. Chinese nation is the descendant of dragon. At the feudal society, dragon is the symbol of empires and kings, who call themselves "true dragon and son of heaven". Up to now, dragon still occupies the highest status in Chinese people, and we call our nation "Oriental dragon". Dragon is the totem of Chinese nation. There are many idioms in Chinese concerning dragon which reflect the cultural implications of dragon in Chinese culture, such as dragons rising and tigers leaping (a scene of bustling 
activity ), like dragons flying and phoenixes dancing (lively and vigorous flourishes in calligraphy ), the dragon and the phoenix bring prosperity(excellent good fortune ), doughty as a dragon and lively as a tiger( full of vim and vigor ).But in Western culture, dragon is an evil and dreadful monster, and is the incarnation of Satan. In the "Holy bible", Satan is called dragon. And dragon is also used to refer to a brutal woman, for example, she is a real dragon, you'd better keep away from her. The cultural differences grant the same animal word different implications and bring people different associations. If people want to express the Chinese concept of "dragon", they'd better translate it into “the Chinese dragon”. For example, “亚洲四小 龙”the four countries with fast economic development in Asia should be translated into "four tigers", rather than "Four dragons" for fear of misunderstanding.

Similarly, phoenix has different implications in English and Chinese. In Chinese traditional culture, phoenix is mysterious and is the king of birds. People would like to refer phoenix to queen. So in Chinese, phoenix is the symbol of "Good luck". However in English, phoenix refers to "purity" and "revival". For example, Religion, like a phoenix, has been resurrected from the ashes of the war.

\section{B. The Differences in Aesthetic Value Orientation and Social Psychology}

The differences in aesthetic value orientation and social psychology grant the same animal different commendatory sense and derogatory sense, which is related to the attitudes of appreciation and detest of the English and Chinese nations towards animals. Love and appreciation towards the animal result in commendatory sense towards the relative animal word. Otherwise, the derogatory sense is developed.

1) The same animal word has completely different commendatory sense and derogatory sense in English and Chinese, such as, dog, owl and bear: Dog is lovely in English bur disgusting in Chinese. The basic meaning of dog in English and Chinese is the same: a domestic animal with four legs, usually kept by human beings for protecting the house. But its cultural implications are completely different. In English, dog has commendatory sense in most cases, referring to a person who is worthy of sympathy and reliable, for example: help a dog over a still, a lucky dog, an old dog, love me, love my dog. Obviously, these expressions reflect English cultural implication that they assume dog as lovely companion and best friend of human, for example, as faithful as a dog is used to describe faithfulness of a person. But in Chinese culture, dog is maltreated, and has evil and awful characters. Many words with dog have derogatory sense, such as: running dog (servile follower), rapacious as a wolf and savage as a cur (heartless and ungrateful), a pack of rogues, stray cur, a bully with backing of a powerful person, and dog eat dog, etc.

Owl is wise in English but ominous in Chinese. In English owl is a wise and witted bird, having such cultural implications as "intelligence and wisdom", for example, as wise as an owl. But in Chinese mind, it is conceived ominous because of its plaintive cries. There is a saying: if owl comes, fortune goes.
The talented bear in English mind and good-for-nothing bear in Chinese mind are quiet different. In oral English, bear refers to a person who has special skill. For example, He is a bear at mathematics. But Chinese people would think of "vexation and good-for-nothing" on talking about bear. There are phrases with derogatory sense, for example, he is good-fornothing and he is vexed.

2) The same animal word has derogatory sense in English in comparison with commendatory sense in Chinese: There are a great many such words, for example, peacock, bat, petrel, magpie and fish, etc.

The proud peacock in English is in confrontation with lucky and beautiful peacock in Chinese. English and Chinese people grant the same animal different associations because of different aesthetic viewpoints. English nation refers peacock to a proud person. There are such phrases as "as proud as a peacock", "play the peacock". But Chinese people focus on the beauty of its tail, peacock is the symbol of luck and beauty in Chinese culture.

The evil bat in English is in confrontation with lucky bat in Chinese. In English, all idioms concerning bat have derogatory sense, such as "as blind as a bat". Bat becomes the typical image of blindness. However in Chinese traditional culture, thanks to the same pronunciation of bat“蝠"and happiness“福”, it becomes lucky symbol.

Compare stormy petrel with brave petrel. Petrel refers to a troublemaker in English, whereas a hero in Chinese. The definition of petrel in "LONGMAN ENGLISH - CHINESE DICTIONARY OF CONTEMPORARY ENGLISH" Is "A stormy petrel is a person whose presence excites discontentment, quarrelling, etc, in a social group." But in Chinese mind, petrel is brave, fearless and forwarding hero and the example for people to learn from. The famous former Soviet Union writer Gao Erji had written "The song of petrel" to praise the spirit of determination and braveness of petrel.

Compare unpleasant magpie and happy magpie. Magpie refers to a talkative person in English, but a lucky bird in Chinese. Chinese people would associate magpie with happy deed, good luck and fortune. People often say "if a magpie sings, good fortune comes". Magpie singing in your house is indeed pleasant in Chinese.

Poor fish in English and prosperous fish in Chinese. Fish has derogatory sense in English, usually implying unfortunate person or thing. For example, a poor fish, a loose fish, fish in the air. However in Chinese, fish has similar pronunciation with "surplus". On Chinese Spring Festival Even, fish is an essential dish. It is said that even in the mountain area where fish is not available, people display carved wooden fish on the table to express their best wishes of grain surplus. The special social customs grant fish different cultural implications. 


\section{LACK OF THE RELEVANT VOCABULARY IN ENGLISH OR CHINESE FOR THE SAME ANIMAL WORD}

\section{A. The Same Animal Word Has Profound Cultural \\ Implications in English, But No Such Relevant Implications in Chinese}

Cat has profound cultural implications in English, for example, rain cats and dogs. But for a Chinese, that expression contributes a lot to difficulty he has in understanding it. There are many more idioms concerning cat, such as, bell the cat, let the cat out of the bag, a cat in the pan, etc. The similar expressions concerning cat are rare in Chinese. Englishmen and Americans compare hardworking, diligent person to beaver, a kind of animal living in North America with special skill and full innovation. But for Chinese who know nothing about its creativity, beaver is only a kind of common animal. Chinese have no association for beaver.

\section{B. The Same Animal Word Has Profound Cultural Implications in Chinese, But No Such Relevant Implications in English}

Silkworm has its root in China. The clothes made of silk are well received by foreigners. "The silk road" was world famous. The silkworm culture has a long history in China. "The spring silkworm produces silk to the last minute of its life, and candle burns to its last second", the poem highly praised the dedication of silkworm. The specific cultural implication of silkworm is deeply rooted in Chinese heart. However for Englishmen, silkworm is just a worm, nothing more. Silkworm reflects cultural differences in English and Chinese.

\section{DiFfERENT ANIMAL Words HAVE THE SAME OR} SIMILAR CULTURAL IMPLICATIONS IN ENGLISH AND CHINESE, NAMELY, THE SAME IMPLICATIONS ARE REFLECTED BY DIFFERENT ANIMAL WORDS IN ENGLISH AND CHINESE

Take "timidity" for example, we Chinese will think of "as timid as a mouse". Chinese people use mouse to describe a person who is timid. But in English, rabbit, chicken and pigeon are used to mean a person who is dreadful, such as, as timid as a rabbit, chicken-hearted or pigeon-hearted. Take "anxiety" for another example, "the ant on hot bricks" is used in Chinese, but "like a cat on hot bricks" in English. In order to mean "brag", "talk cow" is used in Chinese, but "talk horse" in English... In Chinese, cow is often used to describe strength, but horse in English. For example, He is as strong as a horse. For the implication of "stubborn", English expression is "as stubborn as a mule", but "as stubborn as a cow" in Chinese. Referring to a stupid person, "pig" is used in Chinese, but ass in English. For example, make an ass of oneself. "Cat cries for rat" is often used to mean fake mercy and kindness in Chinese, whereas the similar expression is "shed crocodile tears" in English. Chinese people view tiger as the king of animals, and people grant tiger the implication of braveness and powerfulness. But in English, the lion is second to none to mean braveness, for example, as bold as a lion.

The above examples illustrate the same or similar cultural implications of different animal words in English and Chinese. Through the comparative analysis of cultural implications of animal vocabulary in English and Chinese, we can see it clearly that animal vocabulary in any language is not only the sign of animal image, but also the embodiment of cultural differences. Therefore, animal vocabulary is granted profound cultural implications. In order to master vocabulary, we should spare no efforts to understand the implications of the words. By the same token, to understand the cultural implications of the words correctly, we should read extensively and persistently, and study cultural differences. We should read under the lines, avoiding misunderstanding. Only when we deeply understand English cultural traditions and social customs, can we make successful communication and achieve the goal of "have ready plans to meet a situation" in the crosscultural communication.

\section{REFERENCES}

[1] Ma fangxu—Chinese Traditional Animal Culture (Science Press, first edition, April 1, 2015)

[2] Chen Xinqi-oology (6th Edition) (Shanghai Culture Press, September 2009)

[3] Stephen A Mille-College Of The Ozarks John P Harley, EASTERN KENTUCKY UNIV(McGraw-Hill Press, 2007)

[4] (England)George Orwell-Animal farm(From June 25, 1903 to January 21, 1950)

[5] George Akerlof and Robert Schiller-Animal Spirits 